\title{
PENERAPAN MODEL PEMBELAJARAN INQUIRY TRAINING BERBANTUAN SIMULASI PhET TERHADAP KETERAMPILAN PROSES SAINS SISWA
}

\author{
Muliani*, Nanda Novita \\ Dosen Program Studi Pendidikan Fisika, FT Unimal, Aceh Utara \\ Korespondensi: muliani91@unimal.ac.id
}

\begin{abstract}
Abstark: Penelitian ini bertujuan untuk mengetahui apakah keterampilan proses sains siswa yang diajarkan dengan model pembelajaran inquiry training menggunakan media Phet lebih baik dibandingkan dengan pembelajaran direct instruction. Metode yang digunakan dalam penelitian ini adalah quasi experimen menggunakan pretest-posttest control group design. Sampel dalam penelitian ini diambil secara cluster random class, yaitu sebanyak 2 kelas yang berjumlah 80 orang .Instrumen penelitian yaitu instrumen keterampilan proses sains yang terdiri dari 10 soal dalam bentuk essay tes. Data dalam penelitian ini dilakukan uji normalitas dan homogenitas kemudian data dianalisis dengan menggunakan uji independent sampel $t$ test. Hasil data pengujian hipotesis keterampilan proses sains diperoleh nilai signifikan sebesar $0,000<0,05$. Data nilai gain pada kelas kontrol 31,7 \%, sedangkan pada kelas eksperimen diperoleh $63,87 \%$. Kesimpulan yang diperoleh adalahketerampilan proses sains siswa dengan model pembelajaran inquiry trainingberbantuan simulasi Phet lebih baik dari pada pembelajaran direct instruction. Halini menunjukkan ada pengaruh penerapan model pembelajaran inquiry trainingberbantuan simulasi Phet terhadap keterampilan proses sains siswa.
\end{abstract}

Kata Kunci: $\quad$ Model pembelajaran Inquiry Training,Keterampilan Proses Sains, Simulasi Phet

\section{APPLICATION OF INQUIRY TRAINING LEARNING MODEL USING PHET SIMULATION ON THE SKILLS OF STUDENT SCIENCE PROCESS}

This study aims to determine whether students' science process skills taught with inquiry training learning models using Phet media are better than direct instruction learning. The method used in this research is quasi experiment using pretest-posttest control group design. The sample in this study was taken by cluster random class, which is a total of 2 classes totaling 80 people. The research instrument is an instrument of science process skills consisting of 10 questions in the form of test essays. The data in this study were tested for normality and homogeneity then the data were analyzed using the independent sample t test. The results of testing the hypothesis of science process skills obtained a significant value of $0,000<0.05$. The gain value data in the control class was $31.7 \%$, while in the experimental class it was obtained $63.87 \%$. The conclusion obtained is that the science process skills of students with inquiry training learning models assisted by Phet simulation are better than direct instruction learning. This shows that there is an influence on the application of inquiry training learning model assisted by Phet simulation on students' science process skills.

Key words: Inquiry Training learning model, Science Process Skills, Phet Simulations 


\section{PENDAHULUAN}

Pendidikan sains diarahkan pada pengembangan keterampilan dan kemampuan siswa untuk pemecahan masalah kehidupan sehari-hari, berpikir kritis, dan juga meyakinkan bahwa semua siswa memperoleh pengetahuan yang diperlukan untuk latihan tanggung jawab sosial serta mengatasi masalah kehidupan dalam masyarakat yang selalu mengalami perubahan yang kompleks dan dinamis. Ilmu Pengetahuan Alam (IPA) merupakan bagian dari sains yang berkaitan dengan cara mencari tahu tentang alam secara sistematis, sehingga IPA bukan hanya penguasaan kumpulan pengetahuan yang berupa fakta-fakta, konsep-konsep, atau prinsip-prinsip saja tetapi juga merupakan suatu proses penemuan. Pendidikan IPA diharapkan dapat menjadi wahana bagi siswa untuk mempelajari diri sendiri dan alam sekitar, serta pengembangan lebih lanjut dalam menerapkannya di dalam kehidupan sehari-hari (Trianto, 2010:136)

IPA Fisika bagian dari sains terdiri dari tiga aspek yang tidak terpisahkan yaitu proses, produk, dan sikap. Aspek produk terdiri dari fakta, konsep, prinsip, hukum, dan teori. Fisika bukan hanya produk berupa pengetahuan tetapi juga sebagai proses dalam memperoleh pengetahuan tersebut. Proses yang dimaksud disini adalah proses kegiatan ilmiah yaitu : kritis terhadap masalah, sehingga peserta didik mampu merasakan adanya masalah,mengembangkan hipotesis atau pertanyaan-pertanyaan, merancang percobaan, atau melakukan pengamatan untuk menjawab pertanyaan dan menarik kesimpulan.

Proses kegiatan ilmiah dapat dikembangkan antara lain melalui keterampilan proses sain. Keterampilan Proses Sains (KPS) penting dimiliki oleh setiap individu sebagai modal dasar bagi seseorang agar memecahkan masalah hidupnya dalam kehidupan sehari-hari (Trianto, 2010:148).Diungkapkan pula oleh Harlen dan Elstgset (1992:51) menyatakan bahwa KPS adalah keterampilan fisik dan mental terkait dengan kemampuan-kemampuan yang mendasar yang dimiliki, dikuasai dan diaplikasikan dalam suatu kegiatan ilmiah, sehingga para ilmuwan berhasil menemukan sesuatu yang baru. Disamping sebagai sebuah pendekatan dalam pembelajaran sains, keterampilan proses merupakan keterampilan yang harus dimiliki anak sebagai modal dasar memahami ilmu sains. Dalam hal ini, terbentuknya pengetahuan dalam sains dilakukan melalui proses yang ilmiah (metode ilmiah).

Menurut (Henda W Sihaloho, dkk 2017) Keterkaitan inkuiri taining terhadap KPS yaitu keterampilan proses sains dan hasil belajar siswa diajarkan oleh model pembelajaran pelatihan inquiry training lebih baik dari pada pembelajaran konvensional.Hasil penelitian yang dialkukan oleh Ika wardhani dan Djukri (2019) menunjukkan bahwa model inkuiri dengan pendekatan eksperimen pemula secara efektif memiliki dampak signifikan dalam meningkatkan keterampilan proses sains siswa.Santro Nomember Manalu, dkk (2018) bahwa model inquiry training memiliki dampak signifikan pada keterampilan proses sains dan hasil belajar peserta didik.

Pemilihan model pembelajaran yang tepat dapat meningkatkan keterampilan proses sains siswa menjadi lebih baik.. Salah satu model pembelajaran yang dapat meningkatkan keterampilan proses sains siswa adalah model pembelajaran inquiry training.Model pembelajaran inquiry training dirancang membawa siswa secara langsung ke dalam proses ilmiah melalui latihan-latihan yang dapat memadatkan proses ilmiah tersebut kedalam periode waktu yang singkat. Tujuannya adalah membantun siswa mengembangkan disiplin dan mengembangkan keterampilan intelektual yang dapat diperlukan untuk mengajukan pertanyaan dan menemukan jawaban berdasarkan rasa ingin tahunya. (Joyce Buce, dkk 2011). Inti dari model inquiry training adalah untuk melibatkan siswa dalam penyelidikan masalah dengan luas, membantu siswa mengidentifikasi masalah konseptual atau 
metodologis dalam penyelidikan, mengajak siswa untuk merancang cara untuk mengatasi masalah.

Selain penggunaan model pembelajaran yang bervariasi, pemilihan media pembelajaran juga diperhatikan. Dalam penelitian ini media yang digunakan berupa simulasi virtual. Salah satu contoh simulasi virtual adalah simulasi Physics Education Technology (PhET).Simulasi PhET menekankan hubungan antara fenomena kehidupan nyata dengan ilmu yang mendasari, mendukung pendekatan interaktif dan konstruktivis, memberikan umpan balik, dan menyediakan tempat kerja kreatif (Finkelstein, 2006).

Permasalahannya adalah apakah ada pengaruh model pembelajaran inquiry training berbantuan simulasi phet terhadap keterampilan proses sains siswa. Tujuan yang ingin dicapai dalam penelitian ini adalah untuk mengetahuiketerampilan proses sains siswa dengan model pembelajaran inquiry training menggunakan media Phet dan pembelajaran direct instruction.

\section{METODE}

Penelitian ini dilaksanakan di SMA Negeri 3 Medan, Kecamatan Medan Kota. Metode yang digunakan dalam penelitian ini adalah quasi experimen menggunakan pretes-posttest control group design. Sampel penelitian ini yaitu kelas $X_{7}$ sebagai kelas eksperimen dan kelas $X_{6}$ sebagai kelas kontrol yang dipilih secara cluster random sampling. Sampel terdiri dari satu kelas eksperimen dengan menggunakan model pembelajaran Inquiry Training, dan satu kelas kontrol dengan menggunakan model pembelajaran Direct Instruction..

Variabel dalam penelitian ini terdiri atas dua variabel yaitu variabel bebas dan variabel terikat. Variabel bebas dalam penelitian ini adalah model pembelajaran inquiry training berbantuan simulasi Phet, dan variabel terikat dalam penelitian ini adalah keterampilan proses sains siswa pada materi suhu dan kalor.Desain penelitiannya berupa Two Group PretesPostes Design pada tabel 1 di bawah ini.

\section{Tabel 1. Rancangan Desain Penelitian}

\begin{tabular}{lllc}
\hline Sampel & Pretes & Perlakuan & Poses \\
$\begin{array}{l}\text { Kelas } \\
\text { eksperimen }\end{array}$ & $\mathrm{T}_{1}$ & $\mathrm{X}$ & $\mathrm{T}_{2}$ \\
$\begin{array}{l}\text { Kelas } \\
\text { Kontrol }\end{array}$ & $\mathrm{T}_{1}$ & $\mathrm{Y}$ & $\mathrm{T}_{2}$ \\
\hline
\end{tabular}

Keterangan:

T1 : Pre test

T2 : Post test

$\mathrm{X} \quad$ : Perlakuan (treatment) untuk model pembelajaran Inquiry Training Berbantuan simulasi Phet

Y : Perlakuan (treatment) untuk model pembelajaran Direct Instruction. 
Instrumen keterampilan proses sains yang digunakan untuk mengukur keterampilan proses sains siswa yaitu berupa lembar observasiSedangkan instrumen pendukung dalam penelitian ini adalah RPP dan Lembar Kegiatan Siswa.

\section{HASIL DAN PEMBAHASAN}

Hasil

Dari hasil pengolahan data pretes dan postes keterampilan proses sains siswa untuk masing-masing kelas diperoleh nilai rata-rata dan standar deviasi pada Tabel 2.

Tabel2. Data Pretes Dan Postes

\begin{tabular}{llll}
\hline Sampel & N & Mean & Std Deviation \\
\hline Pretes kontrol & 40 & 38,42 & 7,61 \\
Petes eksperimen & 40 & 36,42 & 7,004 \\
Postes kontrol & 40 & 58,00 & 8,37 \\
Postes eksperimen & 40 & 76,91 & 7,02 \\
\hline
\end{tabular}

Pada Tabel 2 dapat dilihat bahwa bahwa rata-rata pretes pada kelas kontrol adalah 38,42 dan pada kelas eksperimen adalah 36,42. Rata-ratapostes pada kelas kontrol adalah 58,00dan pada kelas eksperimen adalah 76,91 dimana jumlah sampel pada masil-masing kelas adalah 40 orang.

Setelah diperoleh data dilakukan uji prasyarat analisis data yaitu uji normalitas dan homogenitas pada Tabel 3.

Tabel 3. Uji Normalitas pretes dan postes

\begin{tabular}{llll}
\hline \multirow{2}{*}{ Hasil } & \multicolumn{3}{l}{ Kolmogorov-Smirnov } \\
\cline { 2 - 4 } & Statistic & Df & Sig \\
\hline Pretes kontrol & 0,098 & 40 & 0,200 \\
Pretes eksperimen & 0,121 & 40 & 0,146 \\
Postes kontrol & 0,126 & 40 & 0,112 \\
Postes eksperimen & 0,120 & 40 & 0,153 \\
\hline
\end{tabular}

Dari hasil uji normalitas data pada kelas kontrol dan eskperimen didapatkan nilai signifikansi untuk kelas eskperimen dan kontrol lebih besar dari nilai 0,05. Maka data pada kelas kontrol dan eksperimen berdistribusi normal. Selanjutnya dilakukan uji homogenitas.

Tabel 4. Homogenitas pretes dan postes

\begin{tabular}{lll}
\hline Hasil & Levene Statistic & sig \\
\hline Pretes & 0,265 & 0,608 \\
Postes & 2,122 & 0,149 \\
\hline
\end{tabular}


Berdasarkan hasil output pada Tabel 4 uji homogenitas varian dengan menggunakan uji Levene diperoleh nilai sig $>0,05$. Hasil ini menunjukkan bahwa siswa kelaskontrol dan eksperimen berasal dari populasi yang mempunyai varian yang sama, atau kedua kelas tersebut homogen. Berdasarkan hasil uji prasyarat diperoleh bahwa keterampilan proses sains berdistribusi normal dan homogen, maka dilakukan uji hipotesis dengan uji independent sampel t test.

\section{Uji Hipotesis}

Berikut ini hasil uji hipotesis untuk keterampilan proses sains siswa

Tabel 5. Hasil Uji independent sampel t test

\begin{tabular}{lll}
\hline Nilai KPS & Df & Sig (2-tailed) \\
\hline Asumsi Varians Sama & 78,00 & 0,000 \\
Asumsi Varians Tidak Sama & 76,275 & 0,000 \\
\hline
\end{tabular}

Berdasarkan tabel 5 output Uji Sample Independen pada bagaian varaians yang sama diasumsikan diketahui nilai Sig (2-tailed) sebesar 0,000<0,05. Maka sebagaimana dasar pengambilan keputusan bahwa Ho ditolak dan Ha diterima, maka disimpulkan bahwa adanya pengaruh penerapan model pembelajaran inquiry trainingberbantuan simulasi Phet terhadap keterampilan proses sains siswa.

\section{Pembahasan}

Hasil dari penelitian untuk nilai rata-rata pretes keterampilan proses sains kelas directinstruction adalah 38,42 dan nilai rata-rata postes keterampilan proses sains adalah 58,00. Adapun nilai rata-rata pretes keterampilan proses sains kelas inquiry training menggunakan media Phet adalah 36,42 dan nilai rata-rata postes keterampilan proses sains adalah 76,91. Kelas kontrol mengalami peningkatan rata-rata sebesar 19,58 sedangkan kelas eksperimen mengalami peningkatan rata-rata sebesar 40,49. Hal ini menunjukkan bahwa peningkatan keterampilan proses sains pada kelas yang diajarkan dengan model Inquiry Training menggunakan media Phet lebih baik dari pada kelas kontrol yang diajarkan dengan pembelajaran Direct Instruction.

Berdasarkan hasil pengujian hipotesis dengan uji independent sampel $t$ testdiperoleh nilai Sig (2-tailed) sebesar 0,000 $<0,05$ disimpulkan bahwa adanya pengaruh penerapan model pembelajaran inquiry trainingberbantuan simulasi Phet terhadap keterampilan proses sains siswa.Model inquiry training dapat menjadi salah satu alternatif model pembelajaran untuk membantu siswa menerapkan sendiri ide-idenya dan siswa akan dilatih untuk melakukan kegiatan-kegiatan penyelidikan sehingga siswa dapat menemukan informasi yang memang diperlukan. Modelinquiry training dirancang untuk membawa siswa secara langsung kedalam proses ilmiah melalui latihan-latihan yang dapat memadatkan proses ilmiah tersebut kedalam periode waktu yang singkat.

Menurut Joyce Bruce, dkk (2011) mengatakan bahwainquiry trainingakan meningkatkan pemahaman ilmu pengetahuan, produktivitas dalam berpikir kreatif, dan keterampilan-keterampilan dalam memperoleh dan menganalisis informasi. Menurut Trianto 
(2009) Direct Instruction merupakan pembelajaran yang direncanakanbersama oleh guru dan siswa, model ini terutama berpusat pada guru. Sehingga sistem pengelolaan pembelajaran ini harus menjalin keterlibatan siswa terutama melalui memperhatikan, mendengar, tanya jawab yang terencana. Akibatnya terjadi proses pembelajaran yang kurang optimal untuk meningkatkan keterampilan proses sains karena guru membuat siswa menjadi pasif dalam pembelajaran.

Pada pelaksanaan pembelajaran model inquiry training dikombinasikan dengan mengunakan media pembelajaran yaitu media Phet.Penerapan model pembelajaran inquiry training dengan menggunkan media Phet mempermudah peneliti dalam menyampaikan informasi kepada siswa sehingga prosesbelajar mengajar menjadiinovatif dan tidak membosankan bagi siswa.Hal ini sesuai dengan hasil penelitian yang dilakukanNanda Safarati (2017)menyimpulkan bahwa pembelajaran dengan menggunakan media Phet dapat meningkatkan hasil belajar keterampilan proses sains siswa.

Jonny Haratua Panggabean dan Ira Kesuma Sari Tampubolon (2016) menyatakan bahwa ada perbedaan pengaruh pembelajaran yang diterapkan dengan model pembelajaran inkuiri menggunakan simulasi PhET terhadap hasil belajar dan aktivitas belajar siswa. Hal ini dilihat darinilai rata-rata postes siswa kelas eksperimen 68,20sedangkan siswa untuk di kelas kontrol sebesar 43,58 pembelajaran dan Rata-rata keseluruhan nilai aktivitas belajar siswa adalah $68,23 \%$ termasuk kategori cukup aktif.

Pelaksanaan model pembelajaran inquiry training menggunakan media Phet menjadikan siswa lebih aktif dalam pembelajaran, menumbuhkan sikap untuk berani menyampaikan pendapat, berinteraksi dengan teman, dan bertanya pada hal-hal yang kurang dipahami. Pola pembelajaran ini lebih variatif dibandingkan model pembelajaran direct instruction, karena pada penelitian ini siswa pada kelas inquiry training menggunakan media Phet banyak melakukan diskusi bersama dan saling berbagi dalam menyelesaikan masalah sehingga dapat meningatkan prestasi akdemik. Hal ini sesuai dengan penelitian yang dilakukan olehNadziroh Af'idayan, dkk (2018) yang menyatakan bahwa siswa yang diajarkan dengan model pembelajaran inquiry training memilki keterampilan proses sains dan hasil belajar yang baik.

Selain itu siswa yang diajarkan dengan model inquiry training menggunakan media Phet terlibat aktif dalam proses penyelidikan ilmiah karena siswa melakukan eksperimen secara langsung dalam menemukan jawaban terhadap suatu permasalahan yang menyebabkan siswa dilatih dalam keterampilan meneliti. Berbeda halnya dengan pembelajaran direct instruction yang mengedepankan latihan kepada siswa. Pengetahuan diajarkan dengan cara melatih siswa ditunut menghafal pengetahuan yang diberikan guru. Pembelajaran berpusat pada guru, dimana guru mengawali pembelajaran dengan penjelasan serta siswa dpersiapkan untuk menerima penjelasan guru. Siswa tidak terlibat aktif dalam proses kegiatan ilmiah sehingga keterampilan proses sains siswa rendah. Kegiatan yang pasif tersebut berdampak pada lemahnya penyerapan pengetahuan siswa.Pada penelitianini didapatkan bukti yang menguatkan bahwa keterampilan proses sains yang mendapat perlakuan model pembelajaran inquiry training ternyata lebih memiliki perbedaan signifikan dengan siswa yang mendapatkan perlakuan model pembelajaran direct instruction.

Hal ini sejalan dengan penelitian yang dilakukan oleh Hendra W dkk (2017) bahwa ada pegaruh model pembalajaan inquiry training dan pembelajaran konvensional terhadap keterampilan proses sains dan hasil belajar siswa. Hal ini menunjukkan bahwa pembelajaran fisika dengan menggunakan model pembelajaran inquiry training berdampak langsung terhadap peningkatan keterampilan proses sains siswa. 


\section{PENUTUP}

Berdasakan hasil penelitian dan pembahasan dapat disimpulkan terdapat pengaruh pengaruh penerapan model pembelajaran inquiry trainingberbantuan simulasi Phet terhadap keterampilan proses sains siswa. keterampilan proses sains siswa yang diajar menggunakan model pembelajaran inquiry training berbantuan simulasi Phet lebih baik dibandingkan dengan keterampilan proses sains siswa yang diajarkan dengan pembelajaran direct instruction. Dapat dilihat dari hasil uji uji independent sampel t test diperoleh nilai Sig (2tailed) sebesar $0,000<0,05$. Hasil belajar keterampilan proses sains siswa pada kelas kontrol mengalami peningkatan rata-rata sebesar 19,58 sedangkan kelas eksperimen mengalami peningkatan rata-rata sebesar 40,49 .

\section{DAFTAR PUSTAKA}

Finkelstein, N. (2006). Hightech Tools For Teaching Physics:The Physics Education Technology Project. Merlot journal of online learning and teaching, 2 (3): 110121.

Harlen Wynne., \& Elsgeest Jos. (1992). UNESCO Sourcebook for Science in the Primmary School. France: UNESCO.

Hendra W., Sahyar., \& Mariati P.S. (2017). The Effect of Inquiry Training Learning Model on Science Process Skills and Student learning Outcomes. IOSR Journal of Research \& Method in Education, 7(6) : 46-51.

Ika wardhani., \& Djukri. (2019). Teaching science process skill using guided inquiry model with starter experiment approach: An experimental study. Jurnal Pendidikan Biologi Indonesia, 5 (2): 277-284.

Jonny Haratua Panggabean., \& Ira Kesuma Sari Tampubolon,. (2016). Pengaruh Model Pembelajaran Inkuiri Menggunakan Simulasi Phet Terhadap Hasil Belajar Siswa Pada Materi Pokok Optika Geometris Di Kelas X Sman 2 Kabanjahe T.P. 2014/2015. Jurnal Inpafi, 4 (2).

Joyce Bruce., Marshall Weil., \& Emily Calhiun. (2011). Models of Teaching Model-Model Pembelajaran. Yogyakarta: Pustaka Pelajar.

Nadziroh Af'idayanii., Iswan Setiadi., \& Fahmi. (2018).The Effect Of Inquiry Model On Science Process Skills And Learning Outcomes. European Journal of Education Studies. 4 (12) : 177-182.

Nanda Safriati. (2017). Pengaruh Model Scientific Inquiry Menggunakan Media Phet Terhadap Keteampilan Proses Sains Ditinjau Dari keterampilan Berpikir Kritis. Jurnal Pendidikan Fisika. 6 (1) : 33-38.

Santro Nomember Manalu., Motlan., \& Nurdin Siregar. (2018). Efek Model Pembelajaran Inquiry Training Menggunakan Macromedia Flash Dan Kreativitas Terhadap Keterampilan Proses Sains. Jurnal Pendidikan Fisika. 7 (1) : 61-68.

Trianto. (2009). Mendesain Model Pembelajaran Inovatif- Progresif, Jakarta: Kencana.

Trianto. (2010). Model Pembelajaran Terpadu Konsep, Strategi, Dan Implementasinya Dalam Kurikkulum Tingkat Satuan Pendidikan, Jakarta: Bumi Aksara. 